\title{
INCLUSIVE GROWTH POLICY AND INSTITUTIONAL ASSESSMENT: THE CASE OF CENTRAL AND EASTERN EUROPEAN COUNTRIES
}

\author{
Olga Tsapko-Piddubna ${ }^{1}$
}

\begin{abstract}
The article highlights the necessity of inclusive growth and development concept implementation in times of economic and social instability as it is widely recognized as the one that can and should tackle the common long existing problems like poverty, inequality, and insecurity. Thus, the subject of this research is to compare the patterns of inclusive growth and development across economies of Central and Eastern Europe (CEE); and to investigate the driving policies and institutions to countries' inclusive growth and development. The research objective is to highlight policies that would increase equality, economic well-being, and as a result, the competitiveness of CEE countries. Methods. For this purpose, the comparative analysis of CEE countries' inclusive growth and development patterns was done; and the empirical evaluation was done to observe relationship between the Inclusive Development Index and indicators that described economic policies and institutional factors relevant to inclusiveness. In a comparative analysis and a cross-country regression model (for both dependent and independent variables), a recently developed by World Economic Forum performance metric was used. Results. The main findings suggest that the Czech and Slovak Republics are the best performing among CEE countries in inclusive growth and development patterns. On the contrary, Ukraine, Moldova, and Russian Federation are the worst. Economic growth of these countries has not transformed well into social inclusion. Still, there is a great potential for all CEE economies to improve their social inclusiveness in comparison with EU-28 and Norway (the most inclusive economy in 2018). Results of the empirical research indicate that redistributive fiscal policy has little influence on inclusive growth and development. Nevertheless, it should create a public social protection system that is engaged in decreasing poverty, vulnerability, and marginalization without hampering economic growth. Besides, an effective and inclusive redistributive state system of CEE economies should accentuate on supporting human economic opportunities. According to the results of the regression model, positive strong influence on inclusive growth and development is associated with the employment and labour compensation policy that allows people to directly increase their incomes and feel active and productive members of society; the basic services and infrastructure policy which is a necessary ground for present and future human and economic development; the asset building and entrepreneurship policy provides diminishing inequality and rising economic opportunities by fostering medium and small business creation and enlarging possibilities of home and other asset ownership. Altogether these policies would increase broad-based human economic opportunities and consequently both equality, economic well-being, and CEE economies' competitiveness in the long run. The counter-intuitive effect observed in the regression model between education and skills development policy and country's inclusive growth and development needs further investigations, as education is important for social mobility and decrease in income and wealth inequality.
\end{abstract}

Key words: inclusive growth and development, inequality, economic opportunity.

JEL Classification: 011, 015

\section{Introduction}

For decades economists have focused on increasing economic growth and accelerating crosscountry convergence, while paying less attention to distributional concerns. These were neo-classicists, who

\footnotetext{
Corresponding author:

${ }^{1}$ Ivan Franko National University of Lviv, Ukraine.

E-mail: olha.tsapko-piddubna@lnu.edu.ua

ORCID: https://orcid.org/0000-0002-7233-6019
}

considered economic growth as a necessary condition that would bring an increasing wealth and higher living standards to all strata of society. According to economy growth approach many developing countries, including transition economies of Central and Eastern 
Europe (CEE countries - the Czech Republic, Estonia, Hungary, Latvia, Lithuania, Moldova, Poland, Romania, the Russian Federation, the Slovak Republic and Ukraine) were given advices to reform their economies according to neoliberalist set of rules - Washington Consensus. Privatization, trade, and financial liberalization/deregulation were considered as panacea for future sustained economic growth, equal opportunities, and prosperity for all. For a long time, a scarce attention has been devoted to distributional patterns both by politicians and economists. As a result, such transition reforms not only led to development and growth, but also, they have contributed to the redistribution of income and wealth in societies breeding the stronger economic and political influence of more newly created affluent elites.

However, over the past several years, a worldwide consensus has emerged on the need for a more socially inclusive approach to generate economic growth, the approach that pays attention to detrimental macroeconomic effects of income and wealth inequality, inequality of opportunity and poverty. Considering this, inclusive growth, i.e., an economic growth that is distributed fairly across society and creates opportunities for all, has become a central concern in the development literature and in policymaking in many countries. Economies which follow the pattern of inclusive growth and development (top-10 according to World Economic Forum report (WEF, 2018): Norway, Iceland, Luxemburg, Switzerland, Denmark, Sweden, the Netherlands, Ireland, Australia, and Austria) prove to develop more sustainably and less susceptible to political, economic and social instability.

Thus, the primary intension behind this study is to determine policies and institutions which would favour inclusive economic growth and development of CEE economies.

Apart from this, after more than quarter of the century of transition it is interesting to analyse CEE economies' growth and development pattern from the point of inclusiveness. Moreover, for detecting the potential to improve CEE countries' social inclusiveness, it is useful to compare them with EU-28 and Norway - the most inclusive country in the world in 2018.

\section{Literature review}

The concept of inclusive growth came to light in the context of understanding that lowering inequality is vital to long-term sustained economic growth and that diminishing inequality is not a by-product of growth process.

Long before, relatively little attention was paid to inequality and there has been no consensus among economists on the origin of it. In the 19th century, K. Marx in his well-known work "Capital" argued that inequality was a result of exploitation. Later, in the middle of the 20th century, economists believed that "a rising tide lifts all boats", that was economic growth would bring an increasing wealth and higher living standards to all sections of society. According to S. Kuznets (1955), economic growth would suffice to resolve the problems of inequality and poverty.

The neo-classical theoretical justification of inequality is represented in marginal productivity theory, which attempts to explain inequality by arguing that each factor of production is rewarded in line with its contribution to production. According to this theory, as long as there is sufficient competition and free markets, all will receive their just rewards in relation to their true contribution to society. Thus, marginal productivity theory associates higher incomes with greater contribution to society. The more the rich people contribute, which means that the harder they work and the more they save, the better it is for workers, whose wage will rise as a result.

Partially the Kuznets theory was true to industrialized countries in the post-war period - in the 1950s and 1960s every group was advancing, and those with lower incomes were rising most rapidly. Since than the Kuznets original hypothesis has been alternatively tested and as a result any strong evidence have been found for the idea that differences in income would diminish pari passu with economic growth (D. Pini, 2015). The gains created by productivity increase has far from been distributed evenly in societies. Moreover, it is not explained in standard theory how countries with similar technology, productivity and per capita income can significantly differ in their before-tax distribution. The reasons for this are other possible causes of inequality like exploitation, discrimination, exercising of monopoly power, rent seeking and many institutional and political factors.

Recently, economists' views have evolved to understanding that policies driven by an exclusive growth focus can set back inclusion and vice versa, high and persistent inequality can undermine the sustainability of growth itself (IMF, 2017). According to present approach, growth and inequality reduction can be instrumental to each other, and they are a byproduct of a prudent policymaking.

As noted by Nobel laureate - J. Stiglits (2016), rules do matter as they determine how fast the economy grow, and who shares in the benefits of that prosperity. In addition, he argues that under the right rules, shared prosperity and strong economic performance reinforce each other. There is no trade-off, which means we do not have to sacrifice sustained economic growth for the sake of equality. In accordance with equality and economic performance complementarity, J. Stiglits suggests an agenda to tame the growth of wealth among the top and establish rules and institutions that ensure security and opportunity for the middle class. 
Similar views are presented by F. Novokmet, T. Piketty, L. Yang and G. Zucman (2018): the rise in inequality is not inevitable; policies and institutions are important in shaping inequality.

There are more in-depth papers on determinants of inequality. Recent research conducted by S. Cevic and C. Correa-Caro (2020) suggests that fiscal policy needs to be better designed to have a greater redistributive effect in the long term. According to their results, the redistributive impact of fiscal policy is statistically insignificant. Moreover, taxation and government spending policy appear to have the opposing effects on income inequality.

\section{Research objective and methodology}

As economic policy and institutions do matter (as they define the redistribution of national income and are vital for creating opportunities), the research objective of this study is to suggest policies and institutions that would favour CEE economies' inclusive growth and development based on crosscountry regression model. Thus, the empirical evaluation (of the relationship between an indicator of inclusive growth and development, and indicators relevant to inclusive growth policies and institutions) would allow to highlight policies that would increase equality, economic well-being, and competitiveness of CEE countries.

Besides, the other research objective is to follow the CEE economies' inclusive growth and development pattern and to reveal the potential to improve their social inclusiveness based on comparative analysis across these countries. Norway and EU-28 were included into the analysis as a benchmark.

There is considerable literature on evaluating countries' performance based on the most widely used measure of a country's economic progress - GDP. For many years, this indicator has been considered as a useful accounting tool for economic output, value added, and productivity; more frequently it has been even used as a proxy for well-being. WEF argues of an alternative performance metric to evaluate socioeconomic progress which enables to consider the distributional concerns. The performance metric of inclusive growth is represented by number of indicators - Key Performance Indicators - which independently can evaluate progress in different spheres that are relevant to inclusive growth (their growth and development, inclusion, and intergenerational equity and sustainability aspects). At the same time values of these indicators are taken to calculate a composite index - the Inclusive Development Index (IDI). It is worth noting that IDI is a broader index of economic progress and well-being, which shows how the traditional measure of growth - GDP per capita - often falls short. Almost a third of the 103 countries covered in WEF report (WEF, 2018) experienced a decrease in inclusive development scores even though their GDP per capita increased.

As economies grow and develop in inclusive or non-inclusive way, many policies are implemented simultaneously and therefore might influence these processes. A cross-country regression model is suggested to determine the significant influence of relevant to inclusive growth policies and institutions on countries' growth and development. More specifically, we want to increase the understanding of the underlying causal links and assess the quantitative impact of each of these policies on countries' inclusiveness. Thus, a specification of the model is expressed as follows:

IDI $=\alpha+\beta_{1}{ }^{*}$ Education $+\beta_{2}{ }^{*}$ Basic Services +

$\beta_{3}{ }^{*}$ Corruption \& Rents $+\beta_{4}{ }^{*}$ Financial Intimidation + $+\beta_{5}{ }^{*}$ Asset Building $+\beta_{6}{ }^{*}$ Employment $+\beta_{7}{ }^{*}$ Fiscal

Transfers $+\varepsilon_{\text {it }}$

In this model (1) IDI is a dependent variable that represents growth and development processes, and there are seven independent variables that represent the inclusive growth policies and institutions (see Table 1).

These seven independent variables are pillars taken from the framework developed in WEF report (WEF, 2017). The framework represents the ecosystem of structural policy incentives and institutions that widely diffuse the benefits of an expanding national economy in terms of household income, opportunity, economic security, and quality of life.

The empirical research is conducted for 96 world economies using a standard approach in regression analysis - the method of LS. Statistic data used in the analysis are taken from databases of WEF, World Bank (World Development Indicators) and from Credit Suisse report (Credit Suisse, 2017). Data processing is done with EViews (8.0) software.

\section{Results and discussion}

The following part of this paper is devoted to the comparative analysis of CEE countries' inclusive growth and development patterns based on WEF performance metric; and to observation of the relationship between the Inclusive Development Index and indicators that describe economic policies and institutional factors relevant to inclusiveness.

\subsection{The comparative analysis of CEE countries' inclusive growth and development patterns}

Most CEE economies are quite inclusive, and their IDI scores vary with a tendency of higher ones belonging to EU members and lower - to non-EU countries (see Figure 1). 
Table 1

Inclusive Growth Policy and Institution Framework

\begin{tabular}{|c|c|c|c|}
\hline & Framework Pillars & \multicolumn{2}{|c|}{ Types of indicators for delivering inclusive outcomes from growth } \\
\hline 1. & $\begin{array}{l}\text { Education and Skills } \\
\text { Development }\end{array}$ & $\begin{array}{l}\text { a) Access } \\
\text { b) Quality } \\
\text { c) Equity }\end{array}$ & $\begin{array}{l}\text { to what extent is education at all levels accessible, of high quality, and } \\
\text { inclusive in terms of attainment and learning outcomes? }\end{array}$ \\
\hline 2. & $\begin{array}{l}\text { Basic Services and } \\
\text { Infrastructure }\end{array}$ & $\begin{array}{l}\text { a) Basic and Digital Infrastructure } \\
\text { b) Health-related Services and } \\
\text { Infrastructure }\end{array}$ & $\begin{array}{l}\text { to what extent are citizens provided with adequate physical, digital } \\
\text { infrastructure, and high quality, affordable health service? }\end{array}$ \\
\hline 3. & Corruption and Rents & $\begin{array}{l}\text { a) Business and Political Ethics } \\
\text { b) Concentration of Rents }\end{array}$ & $\begin{array}{l}\text { to what extent are broad-based economic opportunity and efficient } \\
\text { allocation of resources through zero tolerance of bribery and } \\
\text { corruption, low barriers to entry, and fair competition in product and } \\
\text { capital markets fostered? }\end{array}$ \\
\hline 4. & $\begin{array}{l}\text { Financial Intermediation of } \\
\text { Real Economy Investment }\end{array}$ & $\begin{array}{l}\text { a) Financial System Inclusion } \\
\text { b) Intermediation of Business } \\
\text { Investment }\end{array}$ & $\begin{array}{l}\text { to what extent does the financial system deploy private savings for } \\
\text { employment generating productive purposes? }\end{array}$ \\
\hline 5. & $\begin{array}{l}\text { Asset Building and } \\
\text { Entrepreneurship }\end{array}$ & $\begin{array}{l}\text { a) Small Business Ownership } \\
\text { b) Home and Financial Asset } \\
\text { Ownership }\end{array}$ & $\begin{array}{l}\text { to what extent does the country foster business creation and home } \\
\text { ownership? }\end{array}$ \\
\hline 6. & $\begin{array}{l}\text { Employment and Labour } \\
\text { Compensation }\end{array}$ & $\begin{array}{l}\text { a) Productive Employment } \\
\text { b) Wage and Non-wage Labour } \\
\text { Compensation }\end{array}$ & $\begin{array}{l}\text { to what extent is the country succeeding in fostering widespread } \\
\text { economic opportunity in the form of robust job creation, broad } \\
\text { labour force participation and decent working conditions? }\end{array}$ \\
\hline 7. & Fiscal Transfers & $\begin{array}{l}\text { a) Tax Code } \\
\text { b) Social Protection }\end{array}$ & $\begin{array}{l}\text { to what extent does a country's tax system countervail income } \\
\text { inequality without undermining economic growth? } \\
\text { to what extent are the country's public social protection systems } \\
\text { engaged in mitigating poverty, vulnerability, and marginalization? }\end{array}$ \\
\hline
\end{tabular}

Source: World Economic Forum (2017)

Among CEE economies, those of the Czech and Slovak Republics have the highest values of IDI. These countries succeeded in making their growth processes more socially inclusive as they have significantly higher scores in IDI ranking than based on GDP per capita among advanced economies (see Table 2). Such trend is also typical to Estonia, Romania, and Moldova. By contrast, Russian Federation and Ukraine have significantly lower rankings in IDI than in GDP per capita, suggesting that their economic growth has not transformed as well into social inclusion. Moreover, Ukrainian IDI score is half lower of conceptually possible score and is the lowest among CEE economies.

Comparing with EU average IDI score, only the score of the Czech Republic is higher among CEE economies. There still exists significant potential for all the rest countries to reach EU level and another great

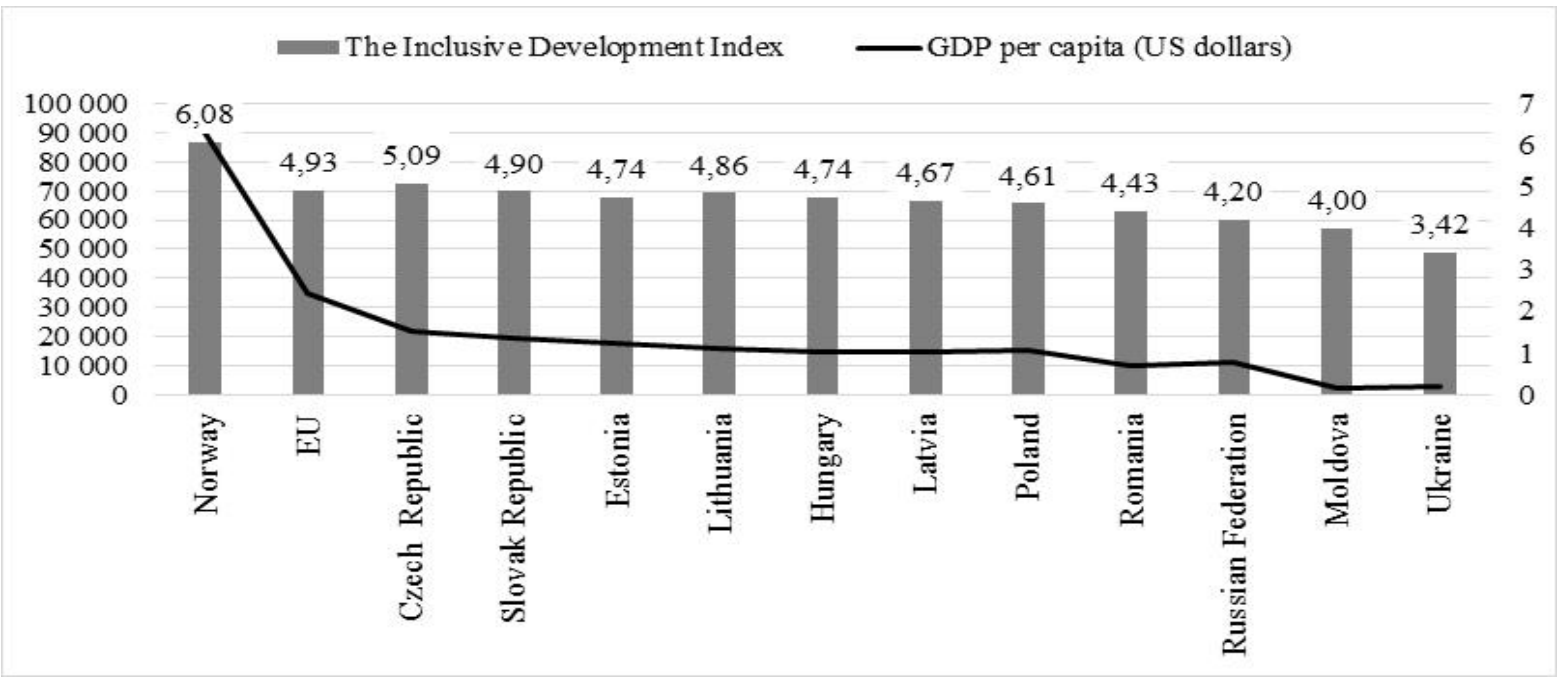

Figure 1.Comparative Performance of IDI versus GDP per capita 2018

Source: World Economic Forum (2018); World Development Indicators Database (2018) 
Table 2

Comparative performance of IDI ranking versus GDP per capita ranking for Norway and CEE countries 2018

\begin{tabular}{|c|c|c|c|c|c|c|c|c|c|c|c|c|}
\hline & \multirow{2}{*}{\multicolumn{4}{|c|}{ Advanced Economies }} & \multicolumn{8}{|c|}{ Emerging Economies } \\
\hline & & & & & \multicolumn{5}{|c|}{ Upper-Middle Income } & \multicolumn{3}{|c|}{ Lower-Middle Income } \\
\hline Rank & 胥 & 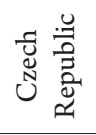 & 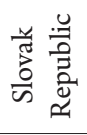 & 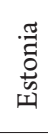 & 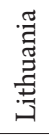 & 㺃 & 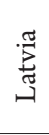 & ָृ & 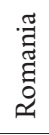 & 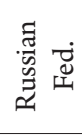 & $\frac{\pi}{0}$ & 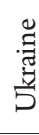 \\
\hline IDI & 1 & 15 & 20 & 22 & 1 & 2 & 4 & 5 & 10 & 19 & 31 & 49 \\
\hline GDP per capita & 2 & 28 & 29 & 30 & 1 & 4 & 5 & 3 & 15 & 9 & 49 & 43 \\
\hline
\end{tabular}

Source: World Economic Forum (2018)

challenge for all CEE countries to move towards the level of Norway.

\subsection{The results of the cross-country regression model}

The coefficient of determination shows that $82 \%$ of the total fluctuations of IDI are due to the influence of independent variables.

Results of the cross-country regression model (1) prove that policies and institutions that provide broad-based equal economic opportunities to all sections of society are the most statistically significant and therefore vital to ensuring inclusive economic growth. Thus, such causal links can be outlined (see Table 3).

Employment and labour compensation policy is the most influential factor of promotion inclusive growth and development. Its positive influence on inclusive growth and development implies fostering of widespread economic opportunity particularly in the form of robust job creation, broad labour force participation and decent working conditions. This policy successful implementation should provide an increase in productive employment (labour force transition from low-productive sectors/industries to high-performing ones and by attracting those who are unemployed) and subsequently increase in employees' incomes and in their self-awareness as of active and productive members of society.

The next significant influence belongs to basic services and infrastructure policy variable. An implementation of this policy is a necessary ground for present and future human and economic development. Such outcomes of its effective implementation as healthy nation (which implies healthy labour force) and an adequate developed physical and digital infrastructure altogether attract investments into economies and increase economic activity there.

The significance of asset building and entrepreneurship variable means that in order to favour more socio-inclusive growth countries should foster medium and small business creation, enlarge possibilities of home and other asset ownership as they are typically the first means by which working households accumulate wealth beyond savings from wages and might serve as a ladder to the middle class and beyond. Stimulating asset building and entrepreneurship with well-known instruments of monetary and fiscal policy, while simultaneously creating the right legislative and institution environment should decrease income and wealth inequality and widen economic opportunities.

Other two variables included in the model financial intimidation of real economy investment, and corruption \& rents are the next statistically significant variables. As these policies are important for economies' inclusive growth and development the effectiveness of their implementation should be also fostered in tackling bribery and corruption, lowering barriers to entry, and fostering fair competition in product and capital markets, enhancing private savings for employment generating productive purposes.

Table 3

Relationship between inclusive growth and development of policies, institutions, and economies

\begin{tabular}{|l|c|c|c|c|c|c|c|}
\hline $\begin{array}{c}\text { Independent } \\
\text { variables: }\end{array}$ & Education & Basic Services & $\begin{array}{c}\text { Corruption \& } \\
\text { Rents }\end{array}$ & $\begin{array}{c}\text { Financial } \\
\text { Intimidation }\end{array}$ & Asset Building & Employment & Fiscal Transfers \\
\hline Coefficient & -0.03 & 0.29 & 0.15 & 0.17 & 0.30 & 0.37 & 0.02 \\
\hline $\mathrm{t}$-statistics & -0.46 & 4.07 & 1.86 & 2.46 & 3.38 & 6.84 & 0.32 \\
(probability) & $(0.64)$ & $(0.00)$ & $(0.06)$ & $(0.01)$ & $(0.00)$ & $(0.00)$ & $(0.74)$ \\
\hline $\mathrm{R}^{2}=0.82 ;$ \\
Adjusted $\mathrm{R}^{2}=0.80$
\end{tabular}

Source: authors' processing in the EViews software 
In our model education and fiscal transfers' policy are insignificant variables.

As it concerns education policy (with its focus on high quality, accessible and inclusive in terms of attainment and learning outcomes education), it is considered to foster widespread economic opportunity, but in our model this variable has insignificant impact and goes in the direction of decreasing the inclusive growth and development.

This goes in the opposite direction to the theory, which states that an increase in education should imply an increase in the skilled labour supply, a decrease in the relative skilled/unskilled wage and an overall decrease in income inequality.

Such a counter-intuitive effect (between education and skills development policy and country's inclusive growth and development pattern) is present in Ukraine. This country is the least inclusive CEE economy (Figure 1), but at the same time the score of education and skills development pillar is the highest (5.86), it is even higher than that of the EU average score - 5.32. Ukrainian education system can be described as supportive of inclusive growth, with high enrolment rates and equitable outcomes for students across socioeconomic levels. But at the same time, it has scarce influence on improvements in inclusiveness of economic growth and development. This counterintuitive effect might have two possible explanations. The first one is that the composed indicator of education and skills development policy does not describe properly the real changes in education and skills development that might have influence on labour productivity. And the second one, the possible positive impact of education policy variable on inclusive growth in Ukraine might be absorbed partially by large-scale migration of qualified workforce (so called brain drain) and partially by lack of productive workplaces. Thus, people in Ukraine are well educated and intelligent but the level of education has little to do with their professional skills; or no matter how educated or skilled they are, they still fulfil the existing vacancies on labour market (which are not highly productive in many developing economies and do respond to their skills qualification) or otherwise emigrate. Those countries, including Ukraine, which pay attention only to the supply of educated work force without creating productive workplaces, eventually prepare its people to emigration. Thus, well developed education and skill policy has no or little impact on inclusiveness of growth and development unless prudent complementary state policies are implemented, in particular policies on stimulating efficient production and providing productive employment and fair labour compensation. The later policies can be a sustainable source to increasing incomes of the employed.

As education is important for social mobility and decrease in income and wealth inequality, its influence on inclusive growth and development processes needs further investigations.

As it concerns redistributive policy of fiscal transfers, it should develop and provide a country's tax system that countervails income inequality without undermining economic growth. Besides, this policy should create such a public social protection system that is engaged in decreasing poverty, vulnerability, and marginalization. At the same time, the developed and effectively functioning system of fiscal transfers is important but not as above policies which directly favour human broad-based economic opportunities.

The insignificance of fiscal transfers' policy variable (consistent with the empirical results of S. Cevic and C. Correa Caro (2020)) might imply its ineffectiveness around the world. For example, in many developed and developing countries there are no effective progressive taxes (on property, inheritance and capital) that would decrease inequality. On the other side, such global tendencies like capital liberalization and deregulation, competition for capital and tax evasion - altogether assist in lowering the accumulated sum of money from national taxpayers. As a result, in many economies around the world the state redistribution system is not functioning effectively.

Some attempts are made around the world to fight tax evasion and to cooperate with other countries in sharing information about personal incomes and assets building. For example, Foreign Account Tax Compliance Act is a legislative effort in the USA to combat tax evasion by U.S. persons holding accounts and other financial assets offshore. Such practices should be followed by other countries.

Thus, CEE countries' governments should better use taxes and transfers to moderate differences in income and wealth. It is suggested to use better well-known fiscal transfers' tools, for example, by making tax system more progressive, scaling back tax deductions, eliminating tax exemptions and by ensuring greater tax compliance.

It is worth noting that in Norway statistically significant variables of our regression model are among the best performing. It would be advisable for developing economies to take Norwegian inclusive growth policies and institutions development pattern as a benchmark.

\section{Conclusions and recommendations}

GDP growth is a necessary but not a sufficient condition for generating inclusive socioeconomic progress and broad-based improvement in living standards. Countries' further development should go in line with inclusive growth theory, supporting economic growth and inequality reduction by prudent policymaking. 
The EU membership obviously stimulates/provides such the inclusive growth policymaking as the EU members - CEE economies have better IDI scores than non-EU countries.

According to this research, inclusive growth and development is not only the matter of redistribution policy. Policies that provide broad-based equal economic opportunities to all sections of society are more vital to ensuring inclusiveness of economy's growth by increasing economic well-being, equality and therefore economies' sustainability and competitiveness. Among them there can be mentioned the employment and labour compensation policy that allows people directly increase their incomes and feel themselves as active and productive members of the society; the basic services and infrastructure policy which is a necessary ground for present and future human and economic development; the asset building and entrepreneurship policy provides diminishing inequality and rising economic opportunities by fostering medium and small business creation and enlarging possibilities of home and other asset ownership.

These policies are determinant to social mobility, decrease in inequality and in the long run are the ground to social and economic stability, and CEE countries' competitiveness.

\section{References:}

Cevik, S., \& Correa-Caro, C. (2020). Taking Down the Wall: Transition and Inequality (IMF working papers). Available at: https://www.imf.org/en/Publications /WP/Issues/2020/02/14/Taking-Down-the-Wall-Transitionand-Inequality-48979

Credit Suisse (2017). Global Wealth Databook 2017. The Credit Suisse Research Institute, 1-165. Available at: https://www.creditsuisse.com/corporate/en/research/research-institute/global-wealth-report.html

International Monetary Fund (2017). Fostering Inclusive Growth. G-20 Leaders' Summit, July 7-8, 2017. IMF working paper, 1-36. Available at: https://www.imf.org/external/np/g20/pdf/2017/062617.pdf

Kuznets, S. (1955). Economic Growth and Income Inequality. American Economic Review, 45 (no. 1), 1-28.

Marx, K. (reprinted in 1976). Capital, Volume 1. Harmondsworth, Penguin Books (HB501 M355 1976).

Novokmet, F., Piketty, T., Yang, L. and Zucman, G. (2018) From Communism to Capitalism: Private Versus Public Property and Inequality in China and Russia. World Inequality Database, no. 2018/2. Available at: https://wid.world/document/communism-capitalism-private-versus-public-property-inequality-china-russiawid-world-working-paper-2018-2/

Pini, D. (2015). The Kuznets Curve and Inequality: A Comparative Study of 27 OECD Countries Across 30 years of Neo-Liberal Economic Policies. Johns Hopkins University Press, 1-38. Available at: https://econ.jhu.edu/wpcontent/uploads/sites/27/2016/02/Pini-The-Kuznets-Curve-and-Inequality.pdf

Stiglitz, J. E. (2016). Rewriting the Rules of the American Economy: An Agenda for Growth and Shared Prosperity. Roosevelt Institute, 1-115. Available at: https://community-wealth.org/sites/clone.community-wealth.org/files/ downloads/report-stiglitz.pdf

World Bank. World Development Indicators Database (2018). Available at: http://databank.worldbank.org/data/ reports.aspx? source $=$ world-development-indicators

World Economic Forum (2018). The Inclusive Development Index 2018 Summary and Data Highlights. WEF working paper, 1-14. Available at: http://www3.weforum.org/docs/WEF_Forum_IncGrwth_2018.pdf

World Economic Forum (2017). The Inclusive Growth and Development Report 2017. WEF working paper, 1-75. Available at: http://www3.weforum.org/docs/WEF_Forum_IncGrwth_2017.pdf 